Maja Kozłowska*

\title{
AUTONOMIA I REGIONALIZM A INTEGRALNOŚĆ PAŃSTWA
}

\section{Region autonomiczny i państwo regionalne}

Widoczna w Europie odmienność polityczna, historyczna i kulturowa wpływa na zróżnicowanie ustrojowe państw, a w bezpośrednim efekcie determinuje pozycję i rolę regionów. Zasada autonomii, wyrażona w wielu systemach konstytucyjnych, zapewnia możliwość „samookreślenia się” danego terytorium, daje dowód jego podmiotowości instytucjonalnej i zapewnia realizację zasady subsydiarności, będącej podstawowym kryterium podziału kompetencji w ramach multilevel constitutionalism.

Samo pojęcie regionalizacji z pewnością nie może ograniczać się do wskazania, jak „podzielić państwo”, lecz dotyczy przede wszystkim kluczowego problemu, jak podzielonymi częściami należycie zarządzać, jaki przyznać im stopień samodzielności i w jaki sposób uniezależnić je od władzy centralnej ${ }^{1}$. Współczesna regionalizacja to niewątpliwie szereg skomplikowanych zależności, w których niemałą rolę odgrywa czynnik polityczny, co szczególnie widoczne jest w obliczu aktualnego hiszpańskiego kryzysu związanego z sytuacją w Katalonii.

* Maja Kozłowska - doktor nauk prawnych, Zakład Prawa i Postępowania Administracyjnego, Uniwersytet Opolski.

1 T. Rabska, Refleksje na temat układu przestrzennego administracji publicznej i jego konsekwencje w zakresie administrowania, RPEiS 1992/2, s. 25. 
Model państwowy określany w literaturze przedmiotu jako „państwo regionalne”, w którym odrębność i samodzielność regionów autonomicznych gwarantowana jest konstytucyjnie, mimo iż prawnie pozostaje ono państwem unitarnym, jest obecnie przedmiotem burzliwej dyskusji politycznej². Podkreśla się, że celem regionu autonomicznego jest urzeczywistnianie treści konstytucyjnych w formie i za pomocą środków określonych przez prawo publiczne w interesie własnego terytorium. Regiony autonomiczne korzystają zatem z szerokiego zakresu zagwarantowanych konstytucyjnie kompetencji legislacyjnych i administracyjnych o charakterze wyłącznym. Rzeczywiste ich wykonywanie zapewniają określone regulacje dotyczące materii finansowej, które odgrywają niezwykle istotną rolę, i którym słusznie przypisuje się charakter „pozafiskalny”3.

Ewolucja systemów regionalnych prowadzi do coraz wyraźniejszego oddalania się od pierwotnie unitarnego modelu państwa, a przyjęte rozwiązania coraz częściej stanowią „zapożyczenia” od klasycznych rozwiązań federalnych, prowadząc niekiedy do zacierania się różnic pomiędzy samym regionalizmem a federalizmem, pomimo odmienności źródeł kształtowania się obydwu procesów.

Jednocześnie państwo regionalne często określane jest jako „nieudany kompromis pomiędzy instancjami unitarnymi i autonomistycznymi” (compromesso mal riuscito fra istanze unitarie e autonomistiche). Pozostaje kwestią dyskusyjną, czy w rzeczywistości jest to kompromis „nieudany”, czy też może rozwiązanie systemowe wychodzące naprzeciw potrzebom dwóch stron, zarówno władzy centralnej, jak i jednostek autonomicznych. Hiszpański kryzys demokracji i towarzysząca mu refleksja nad koniecznością reformy kształtu terytorialnego państwa skłaniają do opowiedzenia się za pierwszym stwierdzeniem.

Instytucjonalny dynamiczny rozwój regionalizmu ma miejsce stosunkowo od niedawna, biorąc pod uwagę fakt, że jego podłoże ideo-

${ }^{2}$ J. Sługocki, Organizacja i funkcjonowanie administracji publicznej we Włoszech. Zagadnienia administracyjnoprawne, Szczecin 2005, s. 80.

${ }^{3}$ Szerzej m.in. F. Puzzo, Il federalismo fiscale, Milano 2002. 
logiczne sięga rewolucji francuskiej. Włosi jako pierwsi powołali do życia państwo regionalne - na mocy konstytucji z 1948 r., jednakże faktyczne powstanie regionów na Półwyspie Apenińskim ma jednak miejsce dużo później, bo dopiero w latach 70. XX w. W tym czasie również Belgia przyjęła konstytucję regionalną, przekształcając się z państwa unitarnego w państwo federalne. W dalszej kolejności możemy wskazać Hiszpanię, gdzie mocą konstytucji z 1978 r. powołano państwo wspólnot autonomicznych.

Można wyróżnić pewne elementy wspólne, które odróżniają system federalny i system regionalny od scentralizowanego państwa unitarnego, takie jak istnienie poziomów terytorialnych pomiędzy władzą centralną a jednostkami podstawowymi - gminami i prowincjami, konstytucyjne zagwarantowanie wspomnianym poziomom kompetencji i - co warte szczególnego podkreślenia - zawarcie wśród nich również kompetencji prawodawczej, co wprowadza tzw. policentryzm legislacyjny.

Zarówno państwa regionalne, jak i federalne znajdują się w ciągłej fazie dynamicznych przemian, co odróżnia je od państwa unitarnego, będącego z zasady modelem o charakterze statycznym. Jednocześnie możemy stwierdzić, że regionalizmy nie reprezentują całkowitej „antytezy federalizmu" - co więcej, w niektórych przypadkach już tworzą „nienazwany federalizm”. Przekazanie kompetencji wiąże się z przekazaniem zasobów, które możemy określić jako decyzyjne (możliwość podejmowania wiążących dla społeczności lokalnych decyzji w określonej sferze kompetencyjnej), administracyjne (instrumenty i zasoby ludzkie konieczne do wywiązania się z przypisanych działań) i finansowe (czyli możliwość pobierania i zarządzania podatkami od ludności).

Niektórzy autorzy przypisują Hiszpanii już charakter państwa quasi-federalnego, zaznaczając, że wśród odstępstw od idealnego modelu należy wskazać na brak senatu o charakterze izby reprezentacji terytorialnej, niedostatecznie rozwinięte stosunki międzynarodowe czy ograniczony zasięg partycypacji wspólnot na płaszczyźnie europejskiej.

\footnotetext{
${ }^{4}$ A. Sroka, Hiszpańska droga do federalizmu, Wrocław 2008, s. 300.
} 
Powraca jednak problem suwerenności, a hiszpański Trybunał Konstytucyjny wyraźnie oddziela autonomię od suwerenności. Jednocześnie, inaczej niż w przypadku Włoch, tradycje odśrodkowe są stałym elementem kształtującym charakter państwa hiszpańskiego. Szczególnie widoczne jest to w odniesieniu do regionów narodowości: Galicji, Kraju Basków i Katalonii. Interesującym elementem charakteryzującym model hiszpański jest jego zróżnicowanie i model kształtowania podziału kompetencji prawodawczych pomiędzy państwo a wspólnoty autonomiczne. Podkreśla się przy tym otwarty charakter systemu - poprzez reformę statutów (mających często charakter regionalnych „minikonstytucji" i będących niekiedy przedmiotem burzliwej dyskusji politycznej) wspólnoty autonomiczne mogą modyfikować swoje kompetencje, oczywiście w ramach norm konstytucyjnych.

W państwach o silnych jednostkach subpaństwowych rząd centralny ma niezwykle trudne zadanie pełnienia funkcji gwaranta jedności porządku prawnego. Regiony/wspólnoty autonomiczne pilnie strzegą swoich konstytucyjnie zagwarantowanych zakresów kompetencyjnych i niechętnie godzą się na interwencje władz centralnych. W wielu przypadkach kluczową rolę odgrywa orzecznictwo sądu konstytucyjnego, którego interpretacja pozwala na doprecyzowanie niekiedy ogólnych i budzących uzasadnione wątpliwości interpretacyjne regulacji konstytucyjnych. W obliczu wydarzeń z 1.10.2017 r. w Katalonii (użycie siły przez oddziały Guardia Civil wobec ludności), a także poprzedzających je działań rządu w Madrycie (aresztowania członków Generalitat, kontrola wydatków regionu, groźba sankcji karnych dla burmistrzów i pracowników administracji publicznej wspierających inicjatywę 1-O), dyskusja nad funkcjonowaniem demokratycznego państwa prawa w Unii Europejskiej oraz zakresem i granicami autonomii jest niezwykle aktualna.

Forma i zakres autonomii nie są jednolite, podlegają dynamicznym przemianom, często ewoluując w kierunku federalizmu. Niewątpli-

${ }^{5}$ J.J. Marco Marco, La proposta di riforma constituzionale spagnola, http://www.issirfa. cnr.it/joaquin-j-marco-marco-la-proposta-di-riforma-costituzionale-spagnola.html (dostęp: 25.10.2018 r.). 
wie należy się zgodzić z poglądem, iż kwestią zasadniczą w ocenie czy też próbie wskazania modelu optymalnego jest to, czy stanowi on system dojrzały, silny, związany z kulturowymi wartościami danego terytorium.

Refleksje nad funkcjonowaniem ustroju politycznego i społeczno-gospodarczego państwa, a co za tym idzie nad kształtem administracji publicznej, nabierają szczególnego znaczenia w epoce dynamicznie rozwijającej się współpracy międzynarodowej i postępującej globalizacji.

Silne państwo regionalne z jasnym określeniem modelu podziału kompetencji prawodawczych pomiędzy władzę centralną a regiony, sprawnymi mechanizmami współpracy, efektywną administracją, zróżnicowaniem pozycji prawnoustrojowej regionów odpowiadającej ich tradycjom historycznym, kulturowym, ale także oczekiwaniom mieszkańców i możliwościom dynamicznego rozwoju, nie będzie jedynie „nieudanym kompromisem pomiędzy unitaryzmem a federalizmem", lecz modelem prawnoustrojowym sprawdzającym się w rzeczywistości krajowej i unijnej. Pojawia się jednak pytanie o środki, jakie należy podjąć, gdy system nie sprawdza się i coraz głośniejsze stają się głosy domagające się zasadniczych reform. Podzielam opinię, że w przypadku kryzysu katalońskiego konieczna jest dyskusja nie tylko nad przyszłością samego regionu autonomicznego, ale także nad formą terytorialną samego państwa hiszpańskiego. Konstruktywna dyskusja, której - w obliczu Brexitu, referendum w Szkocji czy też rysującej się perspektywy Catalanexitu lub też innych silnych ruchów regionalnych - Unia Europejska wydaje się obawiać.

\section{Regiony a Unia Europejska - przyszłość wzajemnych relacji}

Unia Europejska zdeterminowała przezwyciężenie tradycyjnych podziałów terytorialnych pojedynczych państw członkowskich. Ponowne komponowanie jedności ekonomicznej, socjalnej i politycz- 
nej Europy nie mogło obyć się bez przekształcenia relacji, nie tylko pomiędzy poszczególnymi państwami i Unią, ale również pomiędzy państwami a jednostkami terytorialnymín.

Charakter zmian trafnie podsumowuje R. Prud'homme - „państwo z roli solisty przeszło do roli dyrygenta harmonizującego, koordynującego i stymulującego działalność innych podmiotów”" Wraz z decentralizacją administracyjną i pojawieniem się interwencjonizmu samorządowego kluczową rolę w polityce regionalnej zaczęły odgrywać władze terytorialne, które stały się najbardziej predestynowane do ukierunkowywania energii lokalnej i określania miejsca regionu w kontekście krajowym i europejskim ${ }^{8}$.

Rola państwa została w istotny sposób zmodyfikowana, co wiąże się ze zmianą charakteru redystrybucyjnych funkcji państwa i koniecznością uwzględnienia wewnątrzregionalnych czynników rozwoju. Państwo stało się w głównej mierze koordynatorem: w zakresie koordynacji pionowej - między różnymi szczeblami władz publicznych (np. centralnym i samorządowymi, Unią i państwami członkowskimi), a także państwem i przedsiębiorstwami, jak i w zakresie koordynacji poziomej - między władzami, instytucjami i organizacjami szczebla centralnego, a także między podmiotami regionalnymi/lokalnymi ${ }^{9}$ Z decentralizacją wiązała się nieodłącznie konieczność transferów kompensacyjnych dla regionów o niższym stopniu rozwoju, które wymagały pobudzenia dynamiki wzrostu - niezbędny stał się równocześnie wzrost niezależności władz terytorialnych.

Unia Europejska nie ingeruje w rozwiązania systemowe państw członkowskich, problem stopnia decentralizacji, autonomii czy podziału zadań na linii władze centralne-poziom regionalny. Są to wewnętrzne

${ }^{6}$ Szerzej na temat relacji państwo-region w kontekście integracji europejskiej K. Tomaszewski, Regiony w procesie integracji europejskiej, Kraków 2007, s. 159 i n.

7 R. Prud'homme, Les nouveaux objectifs de la politique règionale, „L'Observateur de l'OCDE" 1995, cyt. za I. Pietrzyk, Polityka regionalna Unii Europejskiej i regiony w państwach członkowskich, Warszawa 2002, s. 19.

8 I. Pietrzyk, Polityka..., s. 19.

9 I. Pietrzyk, Polityka..., s. 22. 
sprawy danego państwa; kluczowe jest wypełnianie zobowiązań wynikających z prawa unijnego i terminowe wdrażanie unijnej legislacji, bez względu na to, jaki poziom będzie bezpośrednio zaangażowany w działalność prawodawczą, mającą na celu implementację prawa unijnego (w przypadku państw regionalnych w zakresie kompetencji regionu autonomicznego może to być konieczność wydania odpowiedniej ustawy regionalnej). Podmiotem odpowiedzialnym pozostają zawsze państwa członkowskie. Rola Komitetu Regionów, jakkolwiek była przedmiotem dyskusji i postulowano nawet wzmocnienie jego kompetencji, pozostaje obecnie dość marginalna w obliczu narastających napięć o podłożu autonomistycznym. Kolejnym z pytań w dyskusji jest zatem pytanie o rolę Unii Europejskiej w kontekście bieżących wydarzeń na arenie europejskiej i granice nieingerencji w sprawy wewnętrzne państw członkowskich.

\section{Kryzys kataloński - problem nie tylko hiszpański}

Konstytucja hiszpańska z 1978 r. nie przewiduje możliwości samostanowienia (autodeterminación) narodowości (nacionalidades), tworzących specyficzne państwo złożone, jakim jest Hiszpania. Nie wyrażono również zgody na rozpoczęcie procesu negocjacyjnego w przedmiocie żądania zwołania referendum dotyczącego struktury terytorialnej państwa, którego domagają się Katalończycy i którego przeprowadzenie przeforsowano 1.10.2017 r. Artykuł 2 konstytucji hiszpańskiej wyraża zasadę niepodzielnej jedności narodu hiszpańskiego, jak również solidarności między narodami i regionami, które łączą się z zasadą równości (art. 14 i art. 9 ust. 2). Zasada jedności wyraża się w regulacjach wychodzących od założenia jedności porządku prawnego. Przykładem może być tutaj art. 145, stanowiący, że w żadnym wypadku nie dopuszcza się federacji wspólnot autonomicznych ${ }^{10}$. W opinii konstytucjonalisty J. Pereza Roya wspomniana zasada jed-

${ }_{10}$ Zob. M. Kozłowska, Model państwa regionalnego w Unii Europejskiej: we Włoszech i w Hiszpanii, Wrocław 2012, s. 146 i n. Przewidziano określone normy konstytucyjne, mające pełnić niejako funkcję „gwaranta” jedności państwowej, a tym samym, przynajmniej w teorii, zabezpieczać przed wkroczeniem regionów na teren zarezerwowany dla państwa. 
ności jako limit prawa do autonomii nie determinuje jednak, że państwo musi być jednolite - w ujęciu przeciwstawnym do państwa federalnego, ale mówi jedynie, że w ramach konstytucji nie jest możliwe, żeby narodowość czy region mogły utworzyć niepodległe państwo: autonomia tak, niepodległość nie ${ }^{11}$. Tezę tę potwierdza wcześniejsze i aktualne orzecznictwo hiszpańskiego TC (Tribunal Constitucional) - w sentencji 4/1981 Trybunał ten stwierdza, iż w żadnym wypadku zasada autonomii nie może się przeciwstawiać zasadzie jedności, a co więcej - to w jedności autonomia nabiera swojego prawdziwego znaczenia, w harmonii z art. 2 konstytucji ${ }^{12}$ : „Autonomia zatem nie oznacza suwerenności [...] i ponieważ każda wyposażona w autonomię organizacja terytorialna stanowi równocześnie część całości, nie może ona nigdy stać w sprzeczności z zasadą jedności, lecz realizuje, jak to wynika z art. 2 konstytucji, swoją działalność właśnie w obrębie tej zasady"13.

Można również wskazać na orzeczenie 37/1987, w którym podkreśla się zasadę jedności politycznej, prawnej, ekonomicznej i społecznej Hiszpanii. Wskazana linia interpretacyjna wydaje się powracać w ostatnich orzeczeniach hiszpańskiego TC w odniesieniu do sprawy katalońskiej i jednoznacznym stanowisku w odniesieniu do działań 1-O.

Sprawa katalońska nie przestaje budzić kontrowersji prawnych, ale również silnych emocji wśród wszystkich stron konfliktu. Nie można odmówić słuszności słowom José Ortegi y Gasseta, który w 1932 r. podczas dyskusji w Kongresie Deputowanych nad statutem katalońskim wskazywał na „tragiczny los” katalońskiego problemu, za który nikt nie jest odpowiedzialny: „[...] to sama esencja tego ludu, jego fatalne przeznaczenie, które toczy się udręczone na przestrzeni całej jego historii” („es algo que nadie es responsable; es el cáracter mismo de ese pueblo; es su terrible destino, que arrastra angustioso a lo largo de toda su historia").

\footnotetext{
11 J. Perez Royo, Curso de derecho constitucional, Madrid 2007, s. 864.

${ }_{12}$ M. Kozłowska, Model..., s. 147.

${ }^{13}$ Orzeczenie 4/1981 z 2.02.1981 r., BJC nr 1, s. 7.
} 
Zasadnicze kwestie „katalońskiej kwadratury koła” obejmują: problematykę prawa do samostanowienia (autodeterminación) wspólnoty autonomicznej i jego prawnego uzasadnienia na gruncie prawa krajowego i międzynarodowego; prawo do decydowania o zasadniczych sprawach natury politycznej w postaci referendum czy też konsultacji - i odpowiednio kompetencje wspólnoty autonomicznej w przedmiocie ich zwoływania i przeprowadzania oraz problem reformy konstytucyjnej w celu umożliwienia realizacji separatystycznych dążeń Katalonii.

Niewątpliwe stoimy tu w obliczu problemu polegającego na tym, że jednostka terytorialna dąży do realizacji samostanowienia zewnętrznego (w ramach systemu prawnego niedającego takiej możliwości), a impas ze strony rządu centralnego nie prowadzi do przeprowadzenia reformy konstytucji, która umożliwiłaby rozwiązanie sytuacji ${ }^{14}$. Konieczna byłaby zatem reforma konstytucji, wprowadzająca prawo do samostanowienia zewnętrznego - formalną separację jednostek terytorialnych funkcjonujących w hiszpańskim państwie wspólnot autonomicznych ${ }^{15}$. Ewentualna secesja danej wspólnoty autonomicznej mogłaby mieć miejsce jedynie w sytuacji działania zgodnie z konstytucyjnie przewidzianą procedurą działania.

W przypadku Szkocji było to możliwe dzięki osiągnięciu porozumienia politycznego i wprowadzeniu odpowiednich poprawek legislacyjnych. Zgodnie bowiem ze Scotland Act z 1998 r. unia Szkocji i Anglii jest materią zarezerwowaną dla kompetencji Parlamentu brytyjskiego (the Union of the Kingdoms of Scotland and England, Schedule 5, Part Ib). Jednakże pomimo takiego zastrzeżenia, poprzez porozumienie modyfikujące załącznik 5 - The Scotland Act 1998 (Modification of Schedule 5) Order 2013, z 12.02.2013 r. umożliwiono przeprowa-

${ }_{14}$ Zob. D.E. Tossi, Secessione e Constituzione tra prassi e teoria, Napoli 2007.

15 J.R. Wood, Secession: A comparative analytical framework, „Canadian Journal of Political Science” 1981/16, s. 110, cyt. za B. Aláez Corral, Constitucionalizar la secesión para armonizar la legalidad constitucional y el principio democrático en estados territorialmente descentralizados como España, „Revista d'estudis autonòmics i federals” núm 22, octubre 2015, s. 145. 
dzenie referendum w Szkocji, wprowadzając przepis, że $\$ 1$ nie zastrzega uprawnienia do referendum w przedmiocie odłączenia Szkocji od Wielkiej Brytanii, jeśli zostaną spełnione określone warunki. W przypadku Katalonii do dialogu z Madrytem w przedmiocie przeprowadzenia legalnego referendum regionalnego (czy też referendum ogólnokrajowego, biorąc pod uwagę kwestię charakteru stawianych pytań) nie doszło.

\section{Katalonia - nowe państwo w Europie czy eskalacja kryzysu hiszpańskiej demokracji?}

Aspiracje Katalończyków do przekształcenia wspólnoty autonomicznej w suwerenne państwo oddzielone od Hiszpanii znoszą nadrzędność konstytucji wyrażoną w art. 9.1, wpływają na koncepcję strukturalną państwa autonomicznego, nierozerwalną jedność narodu hiszpańskiego wyrażoną $\mathrm{w}$ art. 2 , jak również przypisaną ludowi hiszpańskiemu suwerenność na mocy art. 1.2. Taka interpretacja pojawia się w orzeczeniu TC nr 31 z 28.06.2010 r. Konieczna byłaby zatem reforma konstytucyjna w oparciu o zaostrzoną procedurę rewizji konstytucji zgodnie z art. 168, co nie wydaje się być zadaniem możliwym do przeprowadzenia przy obecnym układzie sił na hiszpańskiej scenie politycznej.

Termin naród (nación) pojawił się w preambule statutu Katalonii z 2006 r. i został zakwestionowany przed TC jako niezgodny z przepisami konstytucyjnymi, uznającymi naród hiszpański za jedyny podmiot suwerenności. Pojawiły się bowiem wątpliwości, jakie znaczenie (a zatem jakie konsekwencje prawne) miało dla Parlamentu katalońskiego użycie terminu nación w statucie. Trybunał Konstytucyjny wyjaśnił, iż preambuła nie ma charakteru normatywnego, a jedynie interpretacyjny. W opinii Trybunału naród może być zatem rozumiany jako byt kulturowy, historyczno-językowy, socjologiczny czy nawet religijny. Naród związany zaś z suwerennością jest tylko jeden w hiszpańskim porządku prawnym - jest nim naród hiszpański. Sformułowanie statutu katalońskiego nie ma więc jakiegokolwiek wymiaru normatywnego, nie można wywodzić z niego żadnych praw- 
nych konsekwencji. Taka interpretacja Trybunału stała się również przedmiotem licznych dyskusji ${ }^{16}$.

W przedmiocie symboli wspólnoty autonomicznej (hymn, flaga) TC stwierdza, że nie stanowią one symbolu narodu, a narodowości, zgodnie $\mathrm{z}$ art. 2 konstytucji. Jest to zatem uprawnienie niebędące $\mathrm{w}$ opozycji do symboli narodu hiszpańskiego ${ }^{17}$.

Kolejne próby realizacji secesjonistycznych dążeń Katalończyków (po „referendum” z 9.11.2014 r.) osiągnęły swój moment kulminacyjny 1.10.2017 r. Już w czerwcu 2017 r. szef Generalitat, Carles Puigdemont, ogłosił termin referendum niepodległościowego, w którym miało zostać postawione pytanie: „Czy chcesz, aby Katalonia została niepodległym państwem w formie republiki?”. Kolejnym krokiem rządu regionalnego było przegłosowanie 7.09.2017 r. ustawy o referendum i tzw. aktu przejściowego, określającego ramy prawne dla mającej powstać republiki Katalonii, po pozytywnym wyniku głosowania w referendum. Regulacje miałyby wejść w życie w ciągu 48 godzin od ogłoszenia wyników głosowania. W dniu 19.09.2017 r. TC przyjął wniosek rządowy i zawiesił ww. akty prawne. Wykorzystano wszelkie dostępne sposoby w celu uniemożliwienia przeprowadzenia zapowiedzianego na 1 października głosowania (rewizje i konfiskaty przeprowadzane przez Gwardię Cywilną (Guardia Civil), zwiększenie sił rządowych w Katalonii, aresztowania władz regionalnych, zapowiedź pociągnięcia do odpowiedzialności karnej funkcjonariuszy administracji publicznej popierających 1-O, zawieszenie autonomii finansowej regionu poprzez pełną kontrolę wydatków). Po głosowaniu, które zakończyło się korzystnym wynikiem dla zwolenników secesji, podjęto kolejne działania rządowe o wymiarze ekonomicznym, mające na celu rozwiązanie katalońskiego problemu (dekret rządowy upraszczający procedury zmian siedziby spółek). Wyczekiwane oświadczenie Carlesa Puigdemonta w sprawie katalońskiej niepodległości zostało wydane 10.09.2017 r. - wezwał on do dialogu w sprawie „za-

16 Zob. J. Ferret Jacas, Nación, símbolos y derechos históricos, „Revista d’estudis autonòmics i federals" 2011/12, s. 5.

17 J. Ferret Jacas, Nación..., s. 7. 
wieszonej niepodległości” Republiki Katalonii. Odpowiedzią rządu było wezwanie do jednoznacznego potwierdzenia faktu ogłoszenia republiki, czemu towarzyszyło osiągnięcie porozumienia politycznego w celu zastosowania art. 155 konstytucji (oraz reformy samej ustawy zasadniczej w kierunku zwiększonej centralizacji w ciągu 6 miesięcy) w sytuacji pozytywnej odpowiedzi ze strony władz regionu autonomicznego. Przywołany art. 155 pkt 1 stanowi, iż w sytuacji, jeżeli wspólnota autonomiczna nie wykonuje obowiązków, które konstytucja i inne ustawy na nią nałożyły, albo działa w sposób istotnie naruszający interes powszechny Hiszpanii, rząd, po uprzednim bezskutecznym upomnieniu przewodniczącego wspólnoty autonomicznej i za aprobatą większości absolutnej Senatu, może przedsięwziąć środki konieczne do zobowiązania wspólnoty do przymusowego wypełnienia tych obowiązków lub dla ochrony wspomnianego interesu powszechnego. Zgodnie z pkt 2 dla wdrożenia środków rząd może wydawać polecenia wszystkim władzom wspólnot autonomicznych. W związku z brakiem szczegółowych regulacji ustawowych dotyczących działań przewidzianych w art. 155 konstytucji nie można było jednoznacznie wskazać na katalog środków, które miały być zastosowane w przypadku Katalonii.

Wydarzenia jasieni 2017 r. w Katalonii i nasilający się kryzys hiszpańskiej demokracji były przedmiotem uzasadnionych obaw nie tylko w samej Hiszpanii, ale również w Unii Europejskiej. Jakkolwiek pozostaje dyskusyjna kwestia dopuszczalności referendum regionalnego na gruncie aktualnie obowiązującej konstytucji, to jednoznacznie niedopuszczalne jest użycie siły Policji i Gwardii Cywilnej wobec ludności w dniu głosowania 1.10.2017 r. - co niejako wystawiło ocenę stanu hiszpańskiej demokracji, ale i skłoniło do dyskusji o stopniu zaangażowania Unii Europejskiej w omawiany konflikt. Unia Europejska, powołując się na zasadę nieingerencji w sprawy wewnętrzne państw członkowskich, opowiada się za przestrzeganiem porządku prawnego demokratycznego państwa prawa (czy było to demokratyczne państwo prawa 1.10.2017 r.?) i nie skłania się ku roli mediatora konfliktu. Pozostaje otwarte pytanie, kto mógłby (powinien?) taką funkcję objąć, w obliczu sytuacji, w której porozumienie i dialog polityczny wydają się trudne, a wręcz niemożliwe do osiągnięcia. 


\section{Bibliografia:}

Ferret Jacas J., Nación, símbolos y derechos históricos, „Revista d'estudis autonòmics i federals" 2011/12

Kozłowska M., Model państwa regionalnego w Unii Europejskiej: we Włoszech i w Hiszpanii, Wrocław 2012

Marco Marco J.J., La proposta di riforma constituzionale spagnola, http://www. issirfa.cnr.it/joaquin-j-marco-marco-la-proposta-di-riforma-costituzionale-spagnola.html

Perez Royo J., Curso de derecho constitucional, Madrid 2007

Pietrzyk I., Polityka regionalna Unii Europejskiej i regiony w państwach członkowskich, Warszawa 2002

Puzzo F., Il federalismo fiscale, Milano 2002

Prud'homme R., Les nouveaux objectifs de la politique règionale, „L'Observateur de l'OCDE" 1995

Rabska T., Refleksje na temat układu przestrzennego administracji publicznej i jego konsekwencje w zakresie administrowania, RPEiS 1992/2

Sługocki J., Organizacja i funkcjonowanie administracji publicznej we Włoszech. Zagadnienia administracyjnoprawne, Szczecin 2005

Sroka A., Hiszpańska droga do federalizmu, Wrocław 2008

Tomaszewski K., Regiony w procesie integracji europejskiej, Kraków 2007

Tossi D.E., Secessione e Constituzione tra prassi e teoria, Napoli 2007

Wood J.R., Secession: A comparative analytical framework, „Canadian Journal of Political Science" 1981/16 